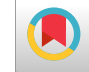

\title{
Association of ANRIL Gene Polymorphisms with Acute Myeloid Leukemia in an Iranian Population
} \author{
Arezou Sayad, ${ }^{1}$ Abbas Hajifathali, ${ }^{2}$ and Mohammad Taheri ${ }^{1,3,}{ }^{*}$ \\ ${ }^{1}$ Department of Medical Genetics, School of Medicine, Shahid Beheshti University of Medical Sciences, Tehran, Iran \\ ${ }^{2}$ Taleghani Bone Marrow Transplantation Center, Shahid Beheshti University of Medical Sciences, Tehran, Iran \\ ${ }^{3}$ Urogenital Stem Cell Research Center, Shahid Beheshti University of Medical Sciences, Tehran, Iran \\ "Corresponding author: Mohammad Taheri, 8th Floor, SBUMS Bldg., Next to Ayatollah Taleghani Hospital, Evin, P. O. Box: 198396-3113, Tehran, Iran. Tel: +98-2177635431, Fax: \\ +98-2177635431, E-mail: mohammad_823@yahoo.com
}

Received 2017 February 25; Revised 2017 May 07; Accepted 2017 October 25.

\begin{abstract}
Background: Recently, in an effort to fully characterize the underlying genetic causes of the acute myeloid leukemia (AML), attention has been devoted to the newest aspect of gene expression regulations which inferred to the regulatory long none coding RNAs. Objectives: ANRIL is one of the disease associated IncRNAs which is transcribed from a critical genomic region that has an important role in the expression regulation of its neighbor genes $C D K N 2 A$ and $C D K N 2 B$ encoding 3 major tumor suppressor genes p14 ${ }^{\mathrm{ARF}}$, p1 ${ }^{\mathrm{INK} 4 \mathrm{~b}}$ and $\mathrm{p} 16^{\mathrm{INK} 4 \mathrm{a}}$.

Methods: Since the identified variants in the CDKN2A and CDKN2B genes or ANRIL locus are reported to be associated with tumorigenesis in different cancers, we investigate 4 single nucleotide polymorphisms (SNP) of ANRIL in Iranian AML patients in comparison to control individuals

Results: The results showed significant association neither for allelic and genotypic frequencies nor for haplotype blocks with AML patients versus control subjects.

Conclusions: With regard to the indicated roles of ANRIL in epigenetic gene expression regulation, exploring its AML-associated genetic defects or its aberrant expression in patients is still a growing area of research and further investigations may illustrate its potential to serve as a diagnostic biomarker or a therapeutic target for AML.
\end{abstract}

Keywords: ANRIL, IncRNA, AML

\section{Background}

As the most common type of leukemia in adults, Acute Myeloid Leukemia (AML) has been estimated to have a growing incidence, prevalence and also a high mortality rate that generally occurred in people with average age of 65 years and affecting men more than women (1).

AML is characterized by an abnormal proliferation of myeloid precursors in the bone marrow that leads to an accumulation of undifferentiated, immature leukemic blasts which waste the potential of the bone marrow to produce enough active normal blood cells including platelets, mature granulocytes, and red blood cells (2).

Any irregularity in key cellular mechanisms such as cell-cycle regulation, stem cell proliferation, differentiation, self-renewal, and apoptosis are hallmarks of pathogenesis of different cancers include AML. These defective cellular processes may be caused by triggering the function of different oncogenes and/or inactivation of various important tumor suppressor genes (3). In this regard, cy- togenetic defects such as losses in the INK4b-ARF-INK4a locus is indicated to be involved in different cancers. Three participants of tumor suppressor networks include $\mathrm{p} 14^{\mathrm{ARF}}$ protein and two members of the INK4 family: p15 $5^{\text {INK4b }}$ and p16 ${ }^{\text {INK4a }}$ that have important regulatory roles in the cellcycle arrest and cell self-renewal encoded by the INK4bARF-INK4a locus at 9p21.3 (4).

On the other hand, this region overlaps the sequence of the Antisense Non-coding RNA in the INK4 Locus (ANRIL) or CDKN2B-AS1 that transcribed to a 3.8 -kb long noncoding RNA. It indicated that IncRNAs participate in the regulation of their neighboring genes through involvement in a crosstalk or a local regulatory networks of connections, and influence the gene expression (5). Besides, previous Genome-wide association analysis have reported several disease-associated single nucleotide polymorphisms (SNPs) in the INK4b-ARF-INK4a locus which were suggested to increase susceptibility to different diseases such as cancers (6-8).

In the present study, based on the functional and clin- 
ical importance of the ANRIL in cancer pathogenesis, the association of 4 SNP markers in the ANRIL sequence were investigated in Iranian AML patients in comparison to healthy controls.

\section{Methods}

\subsection{Participants}

The present case/control study included 202 Iranian de novo AML patients and 400 ethnically, age and sex matched healthy individuals without personal or familial backgrounds of cancer or autoimmune disorders as control group. All the case samples were obtained from the Medical Oncology department of Besat hospital, Hamadan. The diagnosis of patients was made by oncologists according to the revised French-American-British (FAB) classification. The main clinical and laboratory features of the patients are summarized in Table 1. Complete patients with remission, secondary AML, childhood AML, and post treatment were excluded from our study. $5 \mathrm{~mL}$ peripheral blood samples were collected from each individual. This study was approved by the local ethics committee of Hamadan University of Medical Sciences (IR.UMSHA.REC.1395.383). All of the individuals gave an informed written consent agreeing to participate in the present study. Demographic information of patients is demonstrated in Table 1.

Table 1. Demographic and Clinical Datad of AML Patients

\begin{tabular}{lc}
\hline Variables & AML Patient \\
\hline Female/Male $($ No. $(\%))$ & $85(42 \%) / 117(58 \%)$ \\
\hline Age $($ mean $\pm \mathbf{S D}, \mathbf{Y})$ & $33.7 \pm 2.9$ \\
\hline Age range $(\mathbf{Y})$ & $19-65$ \\
\hline Age of onset $($ mean $\pm \mathbf{S D}, \mathbf{Y})$ & $33.4 \pm 2.8$ \\
\hline WBC $\left(\right.$ mean $\left.\pm \mathbf{S D}, \times \mathbf{1 0}^{\mathbf{3}}\right)$ & $50 \pm 7.3$ \\
\hline WBC range $\left(\times \mathbf{1 0}^{\mathbf{3}}\right)$ & $15-150$ \\
\hline Platelet $\left(\mathbf{m e a n} \pm \mathbf{S D}, \times \mathbf{1 0}^{\mathbf{3}}\right)$ & $51 \pm 3.8$ \\
\hline Platelet range $\left(\times \mathbf{1 0}^{\mathbf{3}}\right)$ & $30-300$ \\
\hline Hemoglobin $(\mathbf{m e a n} \pm \mathbf{S D}, \mathbf{g} / \mathbf{d L})$ & $8.3 \pm 1.8$ \\
\hline Hemoglobin range $\left(\times \mathbf{1 0}^{\mathbf{3}}, \mathbf{g} / \mathbf{d L}\right)$ & $4.2-11.5$ \\
\hline
\end{tabular}

\subsection{DNA Extraction and Genotyping}

Genomic DNA for all blood samples were extracted using the standard salting out method. Genotyping for 4 SNPs rs1333045, rs4977574, rs1333048 and rs10757278 were done by tetra-primer amplification refractory mutation system PCR (Tetra-ARMS-PCR). The pair primers using for
PCR were designed by PRIMER1 (9) (Table 2). PCR reaction was performed using Taq $(2 \times)$ red master mix (Ampliqon, Denmark) in a FlexCycler (Analytik Jena, Germany). The cycling PCR protocol was composed of an initial denaturation at $94^{\circ} \mathrm{C}$ for 4 minutes, followed by 35 cycles of $94^{\circ} \mathrm{C}$ for 45 seconds, annealing temperature for 45 seconds and $72^{\circ} \mathrm{C}$ for 55 seconds, with a final extension of $72^{\circ} \mathrm{C}$ for 5 minutes. Specific annealing temperatures were $45^{\circ} \mathrm{C}$ for rs $1333048,53^{\circ} \mathrm{C}$ for rs $4977574,52^{\circ} \mathrm{C}$ for rs 1333045 and $54^{\circ} \mathrm{C}$ for $\operatorname{rs} 10757278$.

\subsection{Statistical Analysis}

Deviation from the Hardy-Weinberg equilibrium for genotype frequency of all 4 SNPs was assessed using the Chi-square test. The association of genotype and allele distribution was evaluated using Pearson Chi-square test by comparing genotype and allele frequencies between the AML patients and the control group by means of SPSS 16.0 (SPSS Inc., Chicago, IL, USA). The calculated results were represented by reporting Odd ratio (OR) and 95\% confidence intervals (CI) for each SNP. The differences in allelic and genotypic distribution between the two groups were considered as significant if the calculated $\mathrm{P}$ value was $\mathrm{P} \leq 0.05$. The haplotype frequencies and their possible association with the disease were calculated using SNPStats online software and the obtained data were reported by describing the $\mathrm{D}^{\prime}$ and $\mathrm{r}^{2} \mathrm{pa}-$ rameters. These analyses were implemented in SNPStats (http://bioinfo.iconcologia.net/SNPstats).

\section{Results}

The results showed that the genotype frequency for all investigated polymorphisms were in agreement with Hardy-Weinberg disequilibrium $\mathrm{P}>0.05$.

The calculated allelic frequencies for all investigated SNPs (rs1333048, rs4977574, rs1333045 and rs10757278) were not significantly different between case and control individuals.

In addition, association analysis between the frequencies of all genotypes for each SNP has shown no significant association to the disease. The detailed data for allele and genotype analysis for both patients and control groups are detailed in Table 3.

In addition, the frequencies of estimated haplotype blocks with at least 0.01 frequency and the results of the association analysis for haplotype blocks between case and controls are shown in Table 4. The haplotype analysis has shown no significant difference between the frequency of estimated haplotype blocks in case and controls in any of the 16 estimated haplotypes. 
Table 2. Sequence of Primes

\begin{tabular}{|c|c|c|c|c|}
\hline Gene & $\begin{array}{c}\text { Genetic } \\
\text { Polymorphism }\end{array}$ & Primer Sequence & Tm & $\begin{array}{c}\text { PCR Product Size } \\
\text { (bp) }\end{array}$ \\
\hline \multirow{32}{*}{ ANRIL } & \multirow{8}{*}{ rs1333048 } & Forward inner primer (A allele): 5' -3' & \multirow{2}{*}{$60^{\circ} \mathrm{C}$} & \multirow{2}{*}{185 bp (A allele) } \\
\hline & & TTAATGCTATTTTGAGGAGATGTCTA & & \\
\hline & & Reverse inner primer (C allele): 5' - $3^{\prime}$ & \multirow{2}{*}{$58^{\circ} \mathrm{C}$} & \multirow{2}{*}{253 bp (C allele) } \\
\hline & & TTTTATCAATATTTCAATAATTCGACACTG & & \\
\hline & & Forward outer primer: 5' - 3' & \multirow{2}{*}{$59^{\circ} \mathrm{C}$} & \multirow{4}{*}{$\begin{array}{c}382 \text { bp (two outer } \\
\text { primers) }\end{array}$} \\
\hline & & TTGCCTGATTACCAATTTTATATGTTA & & \\
\hline & & Reverse outer primer: 5’ -3’ & \multirow{2}{*}{$59^{\circ} \mathrm{C}$} & \\
\hline & & TCAACTGATGATGATATGGTTAGTATG & & \\
\hline & \multirow{8}{*}{ rs4977574 } & Forward inner primer (G allele): 5' - 3’ & \multirow{2}{*}{$66^{\circ} \mathrm{C}$} & \multirow{2}{*}{226 bp (G allele) } \\
\hline & & TTGAGGGTACATCAAAAGCATTCTATATCG & & \\
\hline & & Reverse inner primer (A allele): 5' -3’ & \multirow{2}{*}{$66^{\circ} \mathrm{C}$} & \multirow{2}{*}{166 bp (A allele) } \\
\hline & & TTTATTAGAGTGACTTGAACATCCCGT & & \\
\hline & & Forward outer primer: 5' - 3' & \multirow{2}{*}{$66^{\circ} \mathrm{C}$} & \multirow{4}{*}{$\begin{array}{c}335 \text { bp (two outer } \\
\text { primers) }\end{array}$} \\
\hline & & CACCATTCTTTCTGAAACAACAGGATAT & & \\
\hline & & Reverse outer primer: 5' - 3' & \multirow{2}{*}{$66^{\circ} \mathrm{C}$} & \\
\hline & & AAGGCTCTGACATTTCTAACTCTCTGA & & \\
\hline & \multirow{8}{*}{ rs1333045 } & Forward inner primer (A allele): 5' -3' & \multirow{2}{*}{$63^{\circ} \mathrm{C}$} & \multirow{2}{*}{200 bp (A allele) } \\
\hline & & CgAAGaGCAATAATATATAGTACACTGGGC & & \\
\hline & & Reverse inner primer (C allele): $5^{\prime}-3^{\prime}$ & \multirow{2}{*}{$63^{\circ} \mathrm{C}$} & \multirow{2}{*}{298 bp (C allele) } \\
\hline & & TTAATGAATGCTTACTAGATGCCtGA & & \\
\hline & & Forward outer primer: 5' - 3' & \multirow{2}{*}{$63^{\circ} \mathrm{C}$} & \multirow{4}{*}{$\begin{array}{c}442 \text { bp (two outer } \\
\text { primers) }\end{array}$} \\
\hline & & tGAAAcTTCTTATTTaGtGGtGCATACC & & \\
\hline & & Reverse outer primer: 5' -3' & \multirow{2}{*}{$63^{\circ} \mathrm{C}$} & \\
\hline & & gCagTTCAAAGGAAGTAcCATAAAAAG & & \\
\hline & \multirow{8}{*}{ rs10757278 } & Forward inner primer (A allele): 5' -3' & \multirow{2}{*}{$72^{\circ} \mathrm{C}$} & \multirow{2}{*}{263 bp (A allele) } \\
\hline & & AAGTCAGGGTGTGGTCATTaCGGGAA & & \\
\hline & & Reverse inner primer (C allele): 5' - 3' & \multirow{2}{*}{$68^{\circ} \mathrm{C}$} & \multirow{2}{*}{234 bp (C allele) } \\
\hline & & CTCaGTCTTGATTCTGCATCGCTTCC & & \\
\hline & & Forward outer primer: 5' - 3' & $70^{\circ} \mathrm{C}$ & \\
\hline & & GGGCATTAAGAAAtGGATGGGTAGACAAAA & $70 \mathrm{C}$ & 443 bp (two outer \\
\hline & & Reverse outer primer: 5' - 3' & $70^{\circ} \mathrm{C}$ & primers) \\
\hline & & GCTGTTCtCAAtTAGCCAGGACTACCTCT & 70 & \\
\hline
\end{tabular}

\section{Discussion}

The long non-coding RNA CDKN2B-AS1 also known as ANRIL transcribed from the 9p21.3 genomic region is indicated to be involved in the pathogenesis of different disease such as human cancers. The ANRIL is investigated in different ways to hint at its role in tumorigenesis including its genomic location that overlaps the locus encompassing the INK4b-ARF-INK4a gene cluster which encoded 3 major members of tumor suppressor proteins, $\mathrm{p} 15^{\mathrm{INK} 4 \mathrm{~b}}, \mathrm{p} 14^{\mathrm{ARF}}$, and $\mathrm{p} 16^{\mathrm{INK} 4 \mathrm{a}}$, all of which have a critical role in fundamental biological cell processes such as cell cycle regulation. These important proteins, are alternate reading frames of the $C D K N 2 A$ and $C D K N 2 B$ genes that encodes cyclindependent kinase inhibitors which all act in response to el- 


\begin{tabular}{|c|c|c|c|c|c|}
\hline SNP & Allele/Genotype & Patients, N (\%) & Controls, N (\%) & PValue & OR $(95 \% \mathrm{CI})$ \\
\hline & $\mathrm{C}$ & $238(58.91)$ & $465(58.12)$ & 0.794 & $1.033(0.81-1.317)$ \\
\hline & $\mathrm{T}$ & $166(41.09)$ & $335(41.88)$ & & \\
\hline \multirow[t]{5}{*}{ rs1333045 } & $\mathrm{CC}$ & $66(32.66)$ & $127(31.75)$ & 0.819 & $1.043(0.727-1.498)$ \\
\hline & $\mathrm{CT}$ & $106(52.48)$ & $211(52.75)$ & 0.949 & $0.989(0.705-1.388)$ \\
\hline & $\mathrm{TT}$ & $30(14.86)$ & $62(15.5)$ & 0.835 & $0.951(0.593-1.526)$ \\
\hline & G & $241(59.65)$ & $499(62.37)$ & 0.36 & $0.892(0.698-1.139)$ \\
\hline & A & $163(40.35)$ & $301(37.63)$ & & \\
\hline \multirow[t]{5}{*}{ rs4977574 } & GG & $76(37.63)$ & $160(40)$ & 0.573 & $0.905(0.639-1.281)$ \\
\hline & AG & $89(44.06)$ & $179(44.75)$ & 0.872 & $0.972(0.692-1.367)$ \\
\hline & AA & $37(18.31)$ & $61(15.25)$ & 0.336 & $1.246(0.796-1.952)$ \\
\hline & A & $222(54.95)$ & $449(56.13)$ & 0.698 & $0.954(0.75-1.213)$ \\
\hline & C & $182(45.05)$ & $351(43.87)$ & & \\
\hline \multirow[t]{5}{*}{ rs1333048 } & AA & $65(32.18)$ & $134(33.5)$ & 0.745 & $0.942(0.656-1.351)$ \\
\hline & $\mathrm{AC}$ & $92(45.55)$ & $181(45.25)$ & 0.945 & $1.012(0.72-1.421)$ \\
\hline & $\mathrm{CC}$ & $45(22.27)$ & $85(21.25)$ & 0.772 & $1.062(0.706-1.599)$ \\
\hline & G & $255(63.11)$ & $516(64.5)$ & 0.637 & $0.942(0.735-1.208)$ \\
\hline & A & $149(36.89)$ & $284(35.5)$ & & \\
\hline \multirow[t]{3}{*}{ rs10757278 } & GG & $78(38.61)$ & $162(40.5)$ & 0.655 & $0.924(0.653-1.307)$ \\
\hline & $\mathrm{AG}$ & $99(49.01)$ & $192(48)$ & 0.815 & $1.041(0.742-1.461)$ \\
\hline & AA & $25(12.38)$ & $46(11.5)$ & 0.753 & $1.087(0.647-1.827)$ \\
\hline
\end{tabular}

evated oncogenic signals such as aberrant growth stimulation and interacts with CDK members of the cell cycle regulation pathways which leads to cell cycle arrest and apoptosis (10-12). The expression of the INK4b-ARF-INK4a gene cluster is controlled by the Polycomb group (PcG) proteins that serve to maintain the silent chromatin state of the INK4 locus (13). The epigenetic modifications needed for the silencing function of the $(\mathrm{PcG})$ proteins are provided by two complexes, Poly comb (Pc) repressive complexes (PRC1 and 2). In mammalian PRCs complexes recruited a combination of transcription factors and IncRNAs including ANRIL to target the INK4b-ARF-INK4a locus that leads to repress the gene expression (14).

Several GWAS studies have reported genetic variations in the INK4b-ARF-INK4a region that introduced this region as a susceptibility locus for various disease such as cancers including melanoma, glioma, cervical cancer, and esophageal cancer (15-17). These identified variants could be considered as predisposing factors for cancers through creating a disabled form of mentioned tumor suppressor genes. Also SNPs located in the ANRIL locus have been reported to be strongly associated with increased suscepti- bility to various human diseases (18-20). It is indicated that SNPs located in the 9p21 region can change the expression level of the 3 adjacent genes CDKN2A, CDKN2B, and ANRIL up to 2-fold but the expression level of $C D K N 2 B$, and $A N R I L$ were changed in an opposite way that referred to the antisense regulating role of ANRIL on the expression of the CDKN2B gene that pointed at the consequence of modulations in ANRIL expression that increase the risk of developing human disease (20).

Based on the key regulatory role of the lncRNAs in controlling the expression of neighbor genes (21) and therefore, in cancer development, the SNPs which could change their sequence are expected to influence the risk of tumorigenesis by affecting the expression of lncRNAs.

The evidence of oncogenic role of ANRIL in hematological malignancies was derived from a study that reported an association between rs564398 in the CDKN2BAS locus and acute lymphoblastic leukemia (ALL) (8). In addition an overexpression of ANRIL were reported between ALL and AML patients in comparison to healthy controls while in the same samples the p15 was down regulated (22) Also the expression level of ANRIL was detected to be increased 
Table 4. Haplotype Frequencies and Association Analysis of the ANRIL Polymorphism in the Case and Control Group ${ }^{\mathrm{a}}$

\begin{tabular}{|c|c|c|c|c|}
\hline Haplotypes & Patients, N(\%) & Controls, N(\%) & P Value & OR $(95 \% C I)$ \\
\hline CAAA & $18(4)$ & $48(6)$ & 0.266 & $0.731(0.419-1.273)$ \\
\hline CAAG & $20(5)$ & $24(3)$ & 0.089 & $1.684(0.919-3.087)$ \\
\hline CACA & $4(1)$ & $10(1)$ & 0.691 & $0.79(0.246-2.535)$ \\
\hline CACG & $8(2)$ & $23(3)$ & 0.355 & $0.682(0.303-1.54)$ \\
\hline CGAA & $16(4)$ & $32(4)$ & 0.974 & $0.99(0.536-1.826)$ \\
\hline CGAG & $32(8)$ & $55(7)$ & 0.508 & $1.165(0.741-1.833)$ \\
\hline CGCA & $17(4)$ & $24(3)$ & 0.275 & $1.42(0.754-2.675)$ \\
\hline CGCG & $77(19)$ & $192(24)$ & 0.052 & $0.746(0.554-1.003)$ \\
\hline TAAA & $44(11)$ & $98(12)$ & 0.49 & $0.876(0.6-1.277)$ \\
\hline TAAG & $20(5)$ & $47(6)$ & 0.509 & $0.834(0.487-1.428)$ \\
\hline TACA & $24(6)$ & $31(4)$ & 0.105 & $1.567(0.907-2.707)$ \\
\hline TACG & $16(4)$ & $40(5)$ & 0.419 & $0.784(0.433-1.417)$ \\
\hline T GAA & $36(9)$ & $64(8)$ & 0.589 & $1.125(0.734-1.724)$ \\
\hline T G AG & $24(6)$ & $39(5)$ & 0.433 & $1.232(0.73-2.08)$ \\
\hline TGCA & $16(4)$ & $17(2)$ & 0.066 & $1.899(0.949-3.8)$ \\
\hline T G C G & $32(8)$ & $56(7)$ & 0.562 & $1.143(0.727-1.796)$ \\
\hline
\end{tabular}

${ }^{a}$ Loci chosen for hap-analysis: Site 1 (rs1333045), Site 2 (rs4977574), Site 3 (rs1333048), Site 4 (rs10757278).

in preneoplastic and neoplastic tissues which results in decreased expression of p16INK4a and ultimately reduced senescence (23).

In this regard, four important SNPs of the ANRIL were investigated in the present study in association with AML cancer that included rs10757278 and rs1333045 which were important because of their evolutionary conservation and their impacts on the expression of the ANRIL (24), and also, rs1333048 and rs4977574 which were suggested to be associated with coronary artery disease (CAD) $(25,26)$. The obtained frequencies for all of the 4 investigated SNPs showed a significant difference between case and control groups neither in allelic nor in genotypic distribution. In addition, in order to assess the impact of each allelic changes along with 3 other SNPs the association analysis for the estimated haplotype blocks were done but none of them were associated with AML patients in comparison to healthy controls.

Due to the obtained results we tried to understand whether there are other risk conferring SNPs in the ANRIL genomic region that the expression of ANRIL and thereby its aberrant disrupting consequences may be influenced by those causative variants in linkage disequilibrium with our investigated SNPs. In this regard, we investigated the functional annotation of the explored SNPs and explored other linked SNPs considering the usage of the obtained genomic data from 1000 genome project, epigenetic data from Roadmap Epigenomics project, and gene annotations from ENCODE project. The results revealed several linked SNPs by considering the $\mathrm{D}^{\prime} \geq 0.8$ and $\mathrm{r}^{2} \geq 0.8$ parameters. Each mentioned SNP, itself and its linked polymorphisms, was predicted to overlap different promoter histone marks and enhancer marks in several tissues such as hematopoietic progenitor cells. And also each of the lead SNPs interfere with the different TF binding motifs and consequently their allelic changes altered the binding possibility and led to possible changes in transcription and expression of the gene that needs more functional analysis to be confirmed (27).

\subsection{Conclusion}

Totally, although the results of the present study showed no significant association between any of the analyzed SNPs of the ANRIL gene and the risk of developing AML in Iranian patients, the importance of the gene in the etiology of AML could not be ignored. Further studies are needed to find the exact role of the gene in developing AML, importantly the expression level of this IncRNA should be assessed in patients. Also genotype-phenotype correlations may be useful to determine the impact of the different genetic variants on the risk of developing AML. 


\section{Acknowledgments}

This study was supported by Shahid Beheshti University of Medical sciences.

\section{Footnotes}

Authors' Contribution: None declared.

Conflict of Interest: None declared.

Financial Disclosure: None declared.

\section{References}

1. Deschler B, Lubbert M. Acute myeloid leukemia: epidemiology and etiology. Cancer. 2006;107(9):2099-107. doi: 10.1002/cncr.22233. [PubMed: 17019734].

2. Siegel RL, Miller KD, Jemal A. Cancer statistics, 2016. CA Cancer J Clin. 2016;66(1):7-30. doi: 10.3322/caac.21332. [PubMed: 26742998].

3. Cingeetham A, Vuree S, Dunna NR, Gorre M, Nanchari SR, Edathara $\mathrm{PM}$, et al. Association of caspase9 promoter polymorphisms with the susceptibility of AML in south Indian subjects. Tumour Biol. 2014;35(9):8813-22. doi: 10.1007/s13277-014-2096-5. [PubMed: 24879622].

4. Gil J, Peters G. Regulation of the INK4b-ARF-INK4a tumour suppressor locus: all for one or one for all. Nat Rev Mol Cell Biol. 2006;7(9):667-77. doi:10.1038/nrm1987. [PubMed: 16921403].

5. Engreitz JM, Haines JE, Munson G, Chen J, Perez EM, Kane M, et al. Neighborhood regulation by lncRNA promoters, transcription, and splicing. Bio Rxiv. 2016. doi:10.1101/050948.

6. Stacey SN, Sulem P, Masson G, Gudjonsson SA, Thorleifsson G, Jakobsdottir M, et al. New common variants affecting susceptibility to basal cell carcinoma. Nat Genet. 2009;41(8):909-14. doi: 10.1038/ng.412. [PubMed: 19578363].

7. Turnbull C, Ahmed S, Morrison J, Pernet D, Renwick A, Maranian M, et al. Genome-wide association study identifies five new breast cancer susceptibility loci. Nat Genet. 2010;42(6):504-7. doi: 10.1038/ng.586. [PubMed: 20453838].

8. Iacobucci I, Sazzini M, Garagnani P, Ferrari A, Boattini A, Lonetti A, et al. A polymorphism in the chromosome 9p21 ANRIL locus is associated to Philadelphia positive acute lymphoblastic leukemia. Leuk Res. 2011;35(8):1052-9. doi: 10.1016/j.leukres.2011.02.020. [PubMed: 21414664].

9. Collins A. Primer1, primer design web service for tetra primer ARMS PCR. Open Bioinform J. 2012;6(1):55-8. doi: $10.2174 / 1875036201206010055$.

10. Kuo ML, den Besten W, Bertwistle D, Roussel MF, Sherr CJ. N-terminal polyubiquitination and degradation of the Arf tumor suppressor. Genes Dev. 2004;18(15):1862-74. doi: 10.1101/gad.1213904. [PubMed: 15289458].

11. Hannon GJ, Beach D. p15INK4B is a potential effector of TGFbeta-induced cell cycle arrest. Nature. 1994;371(6494):257-61. doi: 10.1038/371257a0. [PubMed: 8078588].

12. Rayess H, Wang MB, Srivatsan ES. Cellular senescence and tumor suppressor gene p16. Int J Cancer. 2012;130(8):1715-25. doi: 10.1002/ijc.27316. [PubMed: 22025288].
13. Aguilo F, Zhou MM, Walsh MJ. Long noncoding RNA, polycomb, and the ghosts haunting INK4b-ARF-INK4a expression. Cancer Res. 2011;71(16):5365-9. doi: 10.1158/0008-5472.CAN-10-4379. [PubMed 21828241].

14. Popov N, Gil J. Epigenetic regulation of the INK4b-ARF-INK4a locus: in sickness and in health. Epigenetics. 2010;5(8):685-90. [PubMed: 20716961].

15. Shete S, Hosking FJ, Robertson LB, Dobbins SE, Sanson M, Malmer $\mathrm{B}$, et al. Genome-wide association study identifies five susceptibility loci for glioma. Nat Genet. 2009;41(8):899-904. doi: 10.1038/ng.407. [PubMed: 19578367].

16. Wrensch M, Jenkins RB, Chang JS, Yeh RF, Xiao Y, Decker PA, et al. Variants in the CDKN2B and RTEL1 regions are associated with high-grade glioma susceptibility. Nat Genet. 2009;41(8):905-8. doi 10.1038/ng.408. [PubMed: 19578366].

17. Bishop DT, Demenais F, Iles MM, Harland M, Taylor JC, Corda E, et al. Genome-wide association study identifies three loci associated with melanoma risk. Nat Genet. 2009;41(8):920-5. doi: 10.1038/ng.411. [PubMed: 19578364].

18. Motterle A, Pu X, Wood H, Xiao Q, Gor S, Ng FL, et al. Functional analyses of coronary artery disease associated variation on chromosome 9p21 in vascular smooth muscle cells. Hum Mol Genet. 2012;21(18):40219. doi: 10.1093/hmg/dds224. [PubMed: 22706276].

19. Holdt LM, Hoffmann S, Sass K, Langenberger D, Scholz M, Krohn $\mathrm{K}$, et al. Alu elements in ANRIL non-coding RNA at chromosome 9p21 modulate atherogenic cell functions through trans-regulation of gene networks. PLoS Genet. 2013;9(7):1003588. doi: 10.1371/journal.pgen.1003588. [PubMed: 23861667].

20. Congrains A, Kamide K, Oguro R, Yasuda O, Miyata K, Yamamoto E, et al. Genetic variants at the 9p21 locus contribute to atherosclerosis through modulation of ANRIL and CDKN2A/B. Atherosclerosis. 2012;220(2):449-55. doi: 10.1016/j.atherosclerosis.2011.11.017. [PubMed: 22178423].

21. Hauptman N, Glavac D. Long non-coding RNA in cancer. Int J Mol Sci. 2013;14(3):4655-69. doi: 10.3390/ijms14034655. [PubMed: 23443164].

22. Yu W, Gius D, Onyango P, Muldoon-Jacobs K, Karp J, Feinberg AP, et al. Epigenetic silencing of tumour suppressor gene p15 by its antisense RNA. Nature. 2008;451(7175):202-6. doi: 10.1038/nature06468. [PubMed: 18185590].

23. Yap KL, Li S, Munoz-Cabello AM, Raguz S, Zeng L, Mujtaba S, et al. Molecular interplay of the noncoding RNA ANRIL and methylated histone $\mathrm{H} 3$ lysine 27 by polycomb CBX7 in transcriptional silencing of INK4a. Mol Cell. 2010;38(5):662-74. doi: 10.1016/j.molcel.2010.03.021. [PubMed: 20541999].

24. Zhao W, Smith JA, Mao G, Fornage M, Peyser PA, Sun YV, et al. The cis and trans effects of the risk variants of coronary artery disease in the Chr9p21 region. BMC Med Genomics. 2015;8:21. doi: 10.1186/s12920-015 0094-0. [PubMed: 25958224]

25. McPherson R, Pertsemlidis A, Kavaslar N, Stewart A, Roberts R, Cox $\mathrm{DR}$, et al. A common allele on chromosome 9 associated with coronary heart disease. Science. 2007;316(5830):1488-91. doi: 10.1126/science.1142447. [PubMed: 17478681].

26. Denny JC, Bastarache L, Ritchie MD, Carroll RJ, Zink R, Mosley JD, et al. Systematic comparison of phenome-wide association study of electronic medical record data and genome-wide association study data Nat Biotechnol. 2013;31(12):1102-10. doi: 10.1038/nbt.2749. [PubMed: 24270849].

27. Ward LD, Kellis M. HaploReg: a resource for exploring chromatin states, conservation, and regulatory motif alterations within sets of genetically linked variants. Nucleic Acids Res. 2012;40(Database issue):930-4. doi: 10.1093/nar/gkr917. [PubMed: 22064851]. 